attempting to measure the tensile strength of very long nanotubes.

Z. W. Pan, S. S. Xie ${ }^{\star}$, B. H. Chang,

C. Y. Wang, L. Lu, W. Liu,

W. Y. Zhou, W. Z. Li

Institute of Physics, Chinese Academy of Sciences, Beijing 100080, China

*e-mail: user412@aphy01.iphy.ac.cn

L. X. Qian

Department of Physics,

Central University of Nationalities,

Beijing 100081, China

1. Iijima, S. Nature 354, 56-58 (1991)

2. Ebbesen, T. W. \& Ajayan, P. M. Nature 358, 220-222 (1992).

3. Bethune, D. S. et al. Nature 363, 605-607 (1993).

4. Endo, M. et al. Carbon 33, 873-881 (1995).

5. Li, W. Z et al. Science 274, 1701-1703 (1996).

6. Ebbesen, T. W. et al. Nature 382, 54-56 (1996)

7. Fisher, J. E. et al. Phys. Rev. B 55, 4921-4924 (1997).

8. Dai, H. J., Wong, E. W. \& Lieber, C. M. Science 272, 523-526 (1996)

9. Treacy, M. M. J., Ebbesen, T. W. \& Gibson, J. M. Nature 381, 678-680 (1996).

10. Wong, E. W., Sheehan, P. E. \& Lieber, C. M. Science 277, 1971-1975 (1997).

11. Falvo, M. R. et al. Nature 389, 582-584 (1997).

12. Dai, H. J. et al. Nature 384, 147-150 (1996).

13. de Heer, W. A., Chatelain, A. \& Ugarte, D. Science 270, 1179-1181 (1995).

\section{Switch from specialized to generalized pollination}

The once prevalent view that the evolution of extreme ecological specialization is accompanied by a loss of potential for adapting to new conditions, and thus is irreversible ${ }^{1-4}$, has been challenged by several recent examples ${ }^{1,2,5}$. However, we know of no modern phylogenetic studies showing reversal in pollination relationships from extreme specialization to generalization, although such reversals are theoretically expected $^{6,7}$. Here we present molecular phylogenetic evidence for an evolutionary shift in Dalechampia (Euphorbiaceae) vines from a highly specialized relationship (pollination by one or a few animal species ${ }^{2,7}$ ) with resin-collecting bees to generalized pollination by a variety of pollen-feeding insects. This shift was associated with dispersal from Africa to Madagascar, where the specific resin-collecting pollinators are absent. These results show that plants dispersing beyond the range of their specific pollinators may succeed by evolving more generalized pollination systems.

Only a few genera of bees in the families Megachilidae and Apidae use floral resin in nest construction ${ }^{8,9}$, and only two genera of plants, Dalechampia and Clusia (Clusiaceae), are known to secrete resins that attract pollinators ${ }^{8}$. Partly because the reward they offer is non-nutritive, Dalechampia blossoms that secrete resin are pollinated by only one or two species of bees at any one location, and so depend on

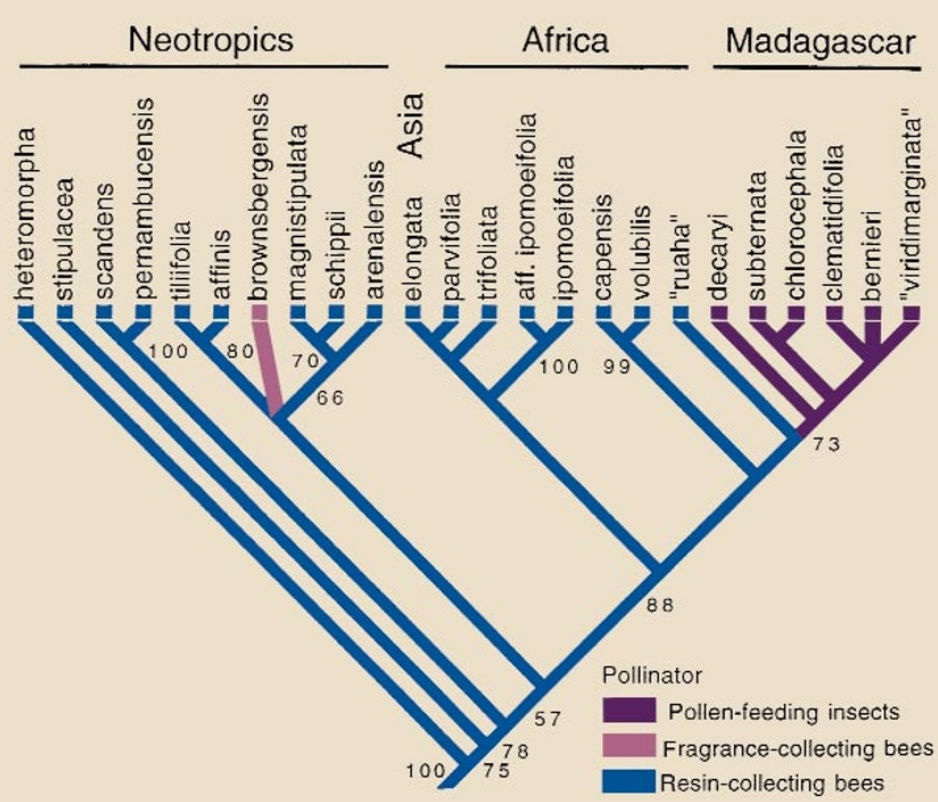

Figure $1 \mathrm{~A}$ phylogenetic hypothesis for Dalechampia sects. Dalechampia and Tilifoliae based on maximum parsimony (MP) analysis of combined nuclear ribosomal (ITS-1, 5,8S, ITS-2) and chloroplast (trnK intron) DNA sequences. The strict consensus of MP trees is depicted, with bootstrap values (above 50\%) along branches. The tree shown is part of a larger tree from an analysis including 16 representatives of the other sections of Dalechampia and two species from candidate sister genera (Plukenetia and Tragia). Evolution of pollination ecology was mapped using MP onto the tree based on the observed pollination of each species. The species are endemic to the regions indicated except $D$. parvifolia, which occurs in both Africa and Asia.

specific pollinators. In eastern and southern Africa, for example, Dalechampia populations are usually pollinated by only one species of Pachyanthidium or Heriades

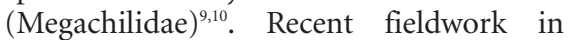
Madagascar has shown that the species of Dalechampia found there offer only pollen as a reward for pollinators, and that most are pollinated by a variety of pollen-feeding insects, including beetles (Cerambycidae, Scarabidae), muscoid flies (Diptera) and several bees (Halictidae, Anthophoridae, Apidae). Open presentation of a common food reward (pollen) results in interactions with numerous pollinators ${ }^{10}$, a finding typical of plants with open flowers ${ }^{6}$.

Phylogenetic analysis of combined nuclear ribosomal and chloroplast DNA data sets, and mapping of pollination and morphological traits onto the molecular tree, indicate that Malagasy species of Dalechampia are descended from an ancestor pollinated by resin-collecting bees (Fig. 1). These results also indicate that Dalechampia colonized Madagascar from Africa (Fig. 1). This finding is further supported by morphological data and biogeographical considerations ${ }^{10}$.

But why did the Malagasy colonists 'abandon' efficient, specialized pollination by resin-collecting bees and switch to a generalized pollination system? It seems that resin-collecting megachilid bees, which are the only pollinators of Dalechampia in Africa ${ }^{9}$, failed to colonize Madagascar ${ }^{10}$. The ancestral Dalechampia colonists of
Madagascar were probably pollinated incidentally by other pollen-feeding insects. They subsequently adapted to the absence of their specific pollinators by losing the gland that secretes the resin reward and by effectively using diverse pollen-feeding insects as pollinators. These changes were sufficiently successful to allow secondary diversification on the isolated island of Madagascar.

\section{W. Scott Armbruster}

Institute of Arctic Biology, University of Alaska, Fairbanks, Alaska 99775, USA

and Department of Botany,

Norwegian University of Science and Technology,

N-7034 Trondheim, Norway

e-mail:ffwsa@uaf.edu

\section{Bruce G. Baldwin}

Jepson Herbarium and Department of Integrative Biology, University of California,

Berkeley, California 94720, USA

1. Futuyma, D. J. \& Morena, G. Annu. Rev. Ecol. Syst. 19, 207-233 (1988).

2. Thompson, J. N. The Coevolutionary Process (Univ. Chicago Press, 1994)

3. Smith, A. B. \& Jeffery, C. H. Nature 392, 69-71 (1998).

4. Givnish, T. J., Sytsma, K. J., Smith, J. F. \& Hahn, W. J. in Hawaiian Biogeography: Evolution on a Hot Spot Archipelago (eds Wagner, W. L. \& Funk, V. A.) 288-337 (Smithsonian Institution Press, Washington D C, 1995).

5. Lanyon, S. M. Science 255, 77-79 (1992).

6. Proctor, M., Yeo, P. \& Lack, A. The Natural History of Pollination (HarperCollins, London, 1996).

7. Waser, N. M., Chittka, L., Price, M. V., Williams, N. M. \& Ollerton, J. Ecology 77, 1043-1060 (1996).

8. Armbruster, W. S. Am. J. Bot. 71, 1149-1160 (1984).

9. Armbruster, W. S. \& Steiner, K. E. Am. J. Bot. 79, 306-313 (1992).

10. Armbruster, W. S. et al. Natl Geogr. Res. Expl. 9, 430-444 (1993). 